\title{
Antiproliferative Withanolides from Datura wrightii
}

\author{
Huaping Zhang, ${ }_{1}^{\dagger}$ Joseph Bazzill, ${ }^{\ddagger}$ Robert J. Gallagher, ${ }^{\dagger}$ Chitra Subramanian, ${ }^{\ddagger}$ Patrick T. Grogan, ${ }^{\ddagger} \S$ \\ Victor W. Day, ${ }^{\perp}$ Kelly Kindscher, "Mark S. Cohen, ${ }^{\ddagger}$ and Barbara N. Timmermann*, ${ }^{\dagger}$ \\ ${ }^{\dagger}$ Department of Medicinal Chemistry, School of Pharmacy, University of Kansas, Lawrence, Kansas 66045, United States \\ ${ }^{\ddagger}$ Division of Endocrine Surgery, Department of Surgery, University of Michigan Hospital and Health Systems, Ann Arbor, Michigan \\ 48109, United States \\ ${ }^{\S}$ Department of Pharmacology, School of Medicine, University of Kansas Medical Center, Kansas City, Kansas 66160, United States \\ ${ }^{\perp}$ The Small-Molecule X-ray Crystallography Laboratory, University of Kansas, Lawrence, Kansas 66047, United States \\ "Kansas Biological Survey, University of Kansas, Lawrence, Kansas 66047, United States
}

\section{Supporting Information}

ABSTRACT: A new withanolide, named withawrightolide (1), and four known withanolides $(\mathbf{2}-\mathbf{5})$ were isolated from the aerial parts of Datura wrightii. The structure of compound 1 was elucidated through 2D NMR and other spectroscopic techniques. In addition, the structure of withametelin L (2) was confirmed by X-ray crystallographic analysis. Using MTS viability assays, withanolides 1-5 showed antiproliferative activities against human glioblastoma (U251 and U87), head and neck squamous cell carcinoma (MDA-1986), and normal fetal lung fibroblast (MRC-5) cells with $\mathrm{IC}_{50}$ values in the range between 0.56 and $5.6 \mu \mathrm{M}$.
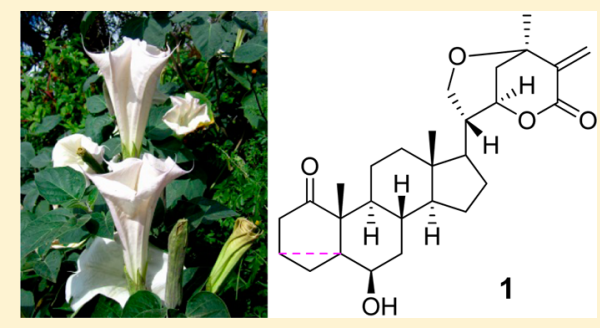

$\mathrm{W}$ ithanolides are a group of modified, highly oxygenated $\mathrm{C}_{28}$ ergostane-type steroids, present primarily in several genera of the Solanaceae, which include Acnistus, Datura, Dunalia, Jaborosa, Physalis, and Withania. In recent years these compounds have gained significant scientific interest due to their structural and biological diversity, in conjunction with their antitumor capacities. ${ }^{1-3}$ Recently we reported, as part of an ongoing study, the isolation and antiproliferative activities of a series of withanolides from Physalis longifolia, Vassobia brevifolia, and Withania somnifera with oxygenation at C-1, 3, $4,5,6,7,11,17,19,20,22,27$, and 28 . $^{4-7}$

The Datura genus is a rich source of oxygen-substituted C-21 withanolides, ${ }^{2}$ yet there have been limited biological activity studies. We therefore chose to investigate the native Kansas plant Datura wrightii Regel to continue our Solanaceae-derived withanolide work and to further probe withanolide structureactivity relationships. ${ }^{3,4}$

We report herein the first phytochemical and bioactivity study of withanolides from $D$. wrightii including all details pertaining to the isolation, structure elucidation, and cytotoxicity (using MTS viability assays) of the new withanolide withawrightolide (1) and four known withanolides (2-5).

Compounds 1-5 were isolated from a $\mathrm{CH}_{2} \mathrm{Cl}_{2}-\mathrm{MeOH}$ (1:1) extract of the aerial parts of the title plant (see Experimental Section). The molecular formula of the minor component 1 was determined to be $\mathrm{C}_{28} \mathrm{H}_{38} \mathrm{O}_{5}$ by HRESIMS and NMR experiments, equating to 10 double-bond equivalents. The IR absorptions of $\mathbf{1}$ indicated the presence of $\mathrm{OH}$ $\left(3435 \mathrm{~cm}^{-1}\right)$ and keto and ester $\left(1740\right.$ and $\left.1705 \mathrm{~cm}^{-1}\right)$ groups. The ${ }^{1} \mathrm{H}$ NMR spectrum (Table 1) showed signals of three methyl groups at $\delta 0.72(3 \mathrm{H}, \mathrm{s}), 1.12(3 \mathrm{H}, \mathrm{s})$, and $1.42(3 \mathrm{H}, \mathrm{s})$; four protons attached to oxygenated carbons at $\delta 3.31(1 \mathrm{H}, \mathrm{t}, J$ $=2.9 \mathrm{~Hz}), 3.71(1 \mathrm{H}, \mathrm{dd}, J=3.3,13.3 \mathrm{~Hz}), 3.87(1 \mathrm{H}, \mathrm{d}, J=13.3$ $\mathrm{Hz})$, and $4.64(1 \mathrm{H}, \mathrm{brs})$; and two olefinic methine groups at $\delta$ $6.00(1 \mathrm{H}, \mathrm{s})$ and $6.75(1 \mathrm{H}, \mathrm{s})$. The ${ }^{13} \mathrm{C} \mathrm{NMR}(\mathrm{APT})$ and HSQC spectra for 1 (Table 1) displayed 28 carbon signals differentiated as three $\mathrm{CH}_{3}, 10 \mathrm{CH}_{2}$ (including an olefinic at $\delta$ 130.3 and an oxygenated at $\delta 60.7$ ), eight $\mathrm{CH}$ (including two oxygenated at $\delta 75.7$ and 73.1), and seven $\mathrm{C}$ (including a keto carbonyl at $\delta 217.7$, an ester carbonyl at $\delta 165.4$, an olefinic at $\delta$ 139.0 , and an oxygenated at $\delta 69.5$ ), corresponding to $\mathrm{C}_{28} \mathrm{H}_{37}$. The remaining hydrogen atom was therefore assigned as an $\mathrm{OH}$ group, indicating that seven rings must be present in the structure.

The NMR data of $\mathbf{1}$ were closely related to a major isolate of our investigation, the six-ringed withanolide withametelin $\mathrm{L}$ (2) $[(20 R, 22 R, 24 R)-21,24$-epoxy- $12 \beta$-hydroxy-1-oxowitha$2,25,25(27)$-trienolide ${ }^{8}$. The structure of 2 was confirmed by $\mathrm{X}$-ray crystallographic studies as shown in Figure 1. Compounds 1 and 2 were found to contain identical bicyclic side chain moieties; an exocyclic double bond [an olefinic methylene C-27 at $\delta_{\mathrm{C}} 130.3$ and two singlet olefinic protons at $\delta_{\mathrm{H}} 6.00$ and 6.75 (each $\left.1 \mathrm{H}, \mathrm{s}, \mathrm{H}_{2}-27\right)$ ] conjugated with the lactone carbonyl (C-26: $\delta_{\mathrm{C}}$ 165.4); characteristic signals for oxygenated C-21 [a methylene with $\delta_{\mathrm{C}} 60.7$ and two protons at $\left.\delta_{\mathrm{H}} 3.87(1 \mathrm{H}, \mathrm{d}, J=13.3 \mathrm{~Hz}), 3.71(1 \mathrm{H}, \mathrm{dd}, J=13.3,3.3 \mathrm{~Hz})\right]$ and C-22 [a methine with $\delta_{\mathrm{C}} 75.7$ and $\left.\delta_{\mathrm{H}} 4.64(1 \mathrm{H}, \mathrm{brs})\right]$; and

Special Issue: Special Issue in Honor of Lester A. Mitscher

Received: January 1, 2012

Published: December 19, 2012 
Table 1. ${ }^{1} \mathrm{H}(500 \mathrm{MHz})$ and ${ }^{13} \mathrm{C}(125 \mathrm{MHz})$ NMR Data for Withawrightolide 1 in $\mathrm{CDCl}_{3}$

\begin{tabular}{|c|c|c|c|c|c|}
\hline position & $\delta_{\mathrm{C}}$, type & $\delta_{\mathrm{H}}(J$ in $\mathrm{Hz})$ & position & $\delta_{\mathrm{C}}$, type & $\delta_{\mathrm{H}}(J$ in $\mathrm{Hz})$ \\
\hline 1 & 217.7, C & & 15 & 24.1, $\mathrm{CH}_{2}$ & $1.73, \mathrm{~m} ; 1.26, \mathrm{~m}$ \\
\hline 2 & $39.6, \mathrm{CH}_{2}$ & 2.81, ddd $(1.7,5.4,18.1) ; 2.14, \mathrm{~d}(18.1)$ & 16 & 26.7, $\mathrm{CH}_{2}$ & $1.74, \mathrm{~m} ; 1.42, \mathrm{~m}$ \\
\hline 3 & $16.0, \mathrm{CH}$ & $1.39, \mathrm{~m}$ & 17 & 47.7, $\mathrm{CH}$ & $1.75, \mathrm{~m}$ \\
\hline 4 & $17.2, \mathrm{CH}_{2}$ & 0.065 , dd $(3.8,5.8) ; 0.78$, ddd $(1.7,5.8,5.9)$ & 18 & 13.0, $\mathrm{CH}_{3}$ & $0.72, \mathrm{~s}$ \\
\hline 5 & 36.0, C & & 19 & $15.0, \mathrm{CH}_{3}$ & $1.12, \mathrm{~s}$ \\
\hline 6 & 73.1, $\mathrm{CH}$ & $3.31, \mathrm{t}(2.9)$ & 20 & $39.8, \mathrm{CH}$ & $1.84, \mathrm{~m}$ \\
\hline 7 & $37.4, \mathrm{CH}_{2}$ & $1.96, \mathrm{~m} ; 1.27, \mathrm{~m}$ & 21 & $60.7, \mathrm{CH}_{2}$ & $3.87, \mathrm{~d}(13.3) ; 3.71, \mathrm{dd}(3.3,13.3)$ \\
\hline 8 & 29.3, $\mathrm{CH}$ & $1.86, \mathrm{~m}$ & 22 & 75.7, $\mathrm{CH}$ & 4.64 , brs \\
\hline 9 & $47.4, \mathrm{CH}$ & 0.97 , ddd $(3.4,10.7,12.2)$ & 23 & $33.5, \mathrm{CH}_{2}$ & 2.0 , dd $(1.7,9.0) ; 1.90, \mathrm{~m}$ \\
\hline 10 & $52.6, \mathrm{C}$ & & 24 & $69.5, \mathrm{C}$ & \\
\hline 11 & $22.2, \mathrm{CH}_{2}$ & $1.42, \mathrm{~m} ; 1.34, \mathrm{~m}$ & 25 & 139.0, C & \\
\hline 12 & $39.5, \mathrm{CH}_{2}$ & $1.89, \mathrm{~m} ; 1.31, \mathrm{~m}$ & 26 & $165.4, \mathrm{C}$ & \\
\hline 13 & 43.3, C & & 27 & $130.3, \mathrm{CH}_{2}$ & $6.75, \mathrm{~s} ; 6.00, \mathrm{~s}$ \\
\hline 14 & $55.8, \mathrm{CH}$ & $1.15, \mathrm{~m}$ & 28 & 25.9. $\mathrm{CH}_{3}$ & $1.42, \mathrm{~s}$ \\
\hline
\end{tabular}

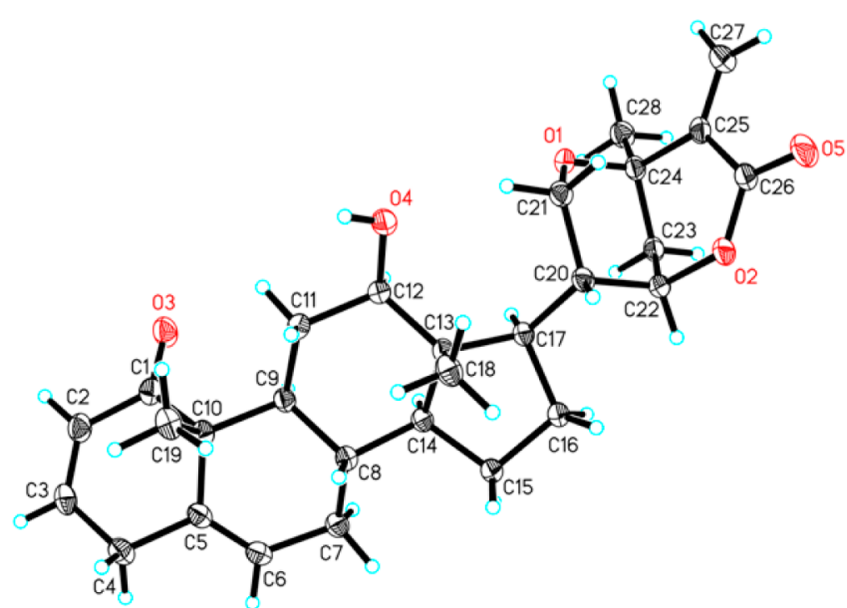

membered ring is less than $210 \mathrm{ppm}$ ) and a cyclopropane ring (when considering the markedly low chemical shift value at $\delta_{\mathrm{H}}$ 0.065 and small geminal coupling constant $5.8 \mathrm{~Hz}$ ), respectively. The presence of 1-oxo-3,5-cyclo-6-hydroxy in the $\mathrm{A} / \mathrm{B}$ rings of the steroid nucleus was deduced by $\mathrm{HSQC}$ and ${ }^{1} \mathrm{H}-{ }^{1} \mathrm{H}$ COSY fragment of $-\mathrm{C}(2) \mathrm{H}_{2}-\mathrm{C}(3) \mathrm{H}-\mathrm{C}(4) \mathrm{H}_{2}-$ and HMBC correlations between $\mathrm{H}_{3}-19(\delta 1.12,3 \mathrm{H}, \mathrm{s})$ and $\mathrm{C}-1(\delta$ $217.7), \mathrm{C}-5(\delta 36.0), \mathrm{C}-9(\delta$ 47.4), and C-10 $(\delta$ 52.6) and between $\mathrm{H}-3(\delta 1.39,1 \mathrm{H}, \mathrm{m})$ and $\mathrm{C}-1, \mathrm{C}-5$, and $\mathrm{C}-6(\delta 73.1)$. The presence of a three-membered ring formed by C-3, C-4, and C-5 was also supported by the chemical shift values of C-3 $(\mathrm{CH}, \delta 16.0)$, C-4 $\left(\mathrm{CH}_{2}, \delta 17.2\right)$, and C-5 (C, $\left.\delta 36.0\right)$. Thus, the planar structure of 1 was represented as shown.

As for the stereochemistry, $\beta$ orientation of the $\mathrm{H}-3$ proton was assigned based on the ROESY correlation between $\mathrm{H}-3$ and $\mathrm{H}_{3}$-19. Axial $\beta$ orientation of the $\mathrm{OH}$ group at $\mathrm{C}-6$ was established by the small coupling constant between H-6 ( $\delta$ $3.31, \mathrm{t}, J=2.9 \mathrm{~Hz})$ and $\mathrm{H}_{2}-7$ and the ROESY correlation between $\mathrm{H}-6$ and $\mathrm{H}-4 \alpha(\delta 0.78,1 \mathrm{H}$, ddd, $J=1.7,5.8,5.9 \mathrm{~Hz})$. These NMR data and assignments were in good agreement with those withanolides reported in the literature with a 1-oxo3,5-cyclo-6-hydroxy functionality in the A/B rings of the steroid nucleus. ${ }^{9,10}$ Accordingly, the structure of 1 was elucidated as $(20 R, 22 R, 24 R)$-21,24-epoxy-3 $\alpha, 5 \alpha$-cyclo-1-oxowitha-25(27)enolide on the basis of biogenetic grounds and subsequently named withawrightolide. Detailed ${ }^{1} \mathrm{H}$ and ${ }^{13} \mathrm{C}$ NMR spectrometric analyses utilizing $2 \mathrm{D}$ correlational techniques were undertaken and are summarized in Table 1.

The four other withanolides were identified through data comparisons with those published in the literature, as withametelin $\mathrm{L}(2){ }^{8}$, withametelin, also known as daturilin (3) ${ }^{11,12}$ withametelin $\mathrm{O}(4),{ }^{8}$ and withametelin $\mathrm{F}(5){ }^{13}$

Withawrightolide (1) contains a cyclopropane ring, a rarity in withanolides. A literature investigation showed that only five of the 820 withanolides reported to date contain a cyclopropane ring: physalin $\mathrm{S}$ isolated from Physalis alkekengi var. francheti ${ }^{9}$ cilistols p, pm, p1, and u from Solanum cilistum (Solanaceae). ${ }^{10}$ This is the first report of such a structural type ${ }^{3}$ present in Datura species.

All the five withanolides (1-5) isolated were tested for

The differences between $\mathbf{1}$ and $\mathbf{2}$ were observed within the steroid nucleus moieties. Compound $\mathbf{1}$ showed unusual NMR signals for a keto group $(\delta 217.7)$ and a methylene group $\left[\delta_{\mathrm{C}}\right.$ $17.2, \delta_{\mathrm{H}} 0.78(1 \mathrm{H}$, ddd, $J=1.7,5.8,5.9 \mathrm{~Hz})$ and $0.065(1 \mathrm{H}, \mathrm{dd}$, $J=3.8,5.8 \mathrm{~Hz})$ ], implying the presence of a five-membered keto ring (the chemical shift value of a keto group in a sixcytotoxicity against human glioblastoma (U251 and U87), head and neck squamous cell carcinoma (MDA-1986), and normal fetal lung fibroblast (MRC-5) cells, the results of which are summarized in Table 2. Withanolides $\mathbf{1 - 5}$ demonstrated cytotoxicity with $\mathrm{IC}_{50}$ values ranging from 0.56 to $3.6 \mu \mathrm{M}$ in 
Table 2. Cytotoxicity $\left(\mathrm{IC}_{50}\right)$ of Isolated Withanolides $(\mu \mathrm{M})$ against Four Cell Lines ${ }^{a}$

$\begin{array}{lllccc}\text { compound } & \text { U87 } & \text { U251 } & \text { MDA-1986 } & \text { MRC-5 } & \text { MRC-5:U87 } \\ \mathbf{1} & 1.5 & 3.6 & 3.1 & 5.6 & 3.8 \\ \mathbf{2} & 0.57 & 1.3 & 2.3 & 4.2 & 7.4 \\ \mathbf{3} & 1.0 & 2.2 & 2.7 & 5.1 & 5.1 \\ \mathbf{4} & 1.1 & 2.8 & 3.0 & 4.6 & 4.1 \\ \mathbf{5} & 0.56 & 1.4 & 1.5 & 3.3 & 6.0 \\ \text { withaferin A }^{b} & 1.1 & 0.69 & 0.80 & 0.20 & 0.19\end{array}$

${ }^{a}$ For cell lines used, see text. ${ }^{b}$ Withaferin A was used as control.

the cancer cells and 3.3-5.6 $\mu \mathrm{M}$ in the normal fibroblasts. Specifically, concentrations required to obtain cytotoxicity in the normal MRC-5 cells were 3.8-7.4-fold higher than those in U87 cells. Our previously published work on a commonly known withanolide, withaferin $A,{ }^{4,13}$ is provided as a control for comparison. The potencies of $\mathbf{1 - 5}$ are on average slightly lower than withaferin $\mathrm{A}$, suggesting that oxygenation of C-21 did not contribute toward the observed antiproliferative activities. Furthermore, the comparison of withanolides 2 (12 $\beta$-hydroxy 3 ) and 3 revealed that oxygenation of $\mathrm{C}-12$ is also not a contributor for antiproliferative activities. These observations are in good agreement with those reported in the literature. ${ }^{3}$ On the other hand, withanolides 1-5 appear to have greater selectivity than withaferin A for cancer cells (especially in the glioma and head and neck squamous cancer cells tested) compared to normal cells such as fibroblasts with average selectivity of between 4- and 7-fold. Such a level of selectivity may provide for a larger therapeutic window for treatment in vivo.

Due to the observed proliferation inhibition of the withanolides 1-5, further U251 cell-based Western blot analysis was performed. Total cell expression of heat shock protein 70 (HSP70) and HSP32, proteins associated with cellular stress and withaferin A activity, ${ }^{13}$ was monitored $24 \mathrm{~h}$ post-treatment (Figure 2). Post-treatment HSP70 upregulation was observed for $5 \mu \mathrm{M}$ concentrations of withanolides 2, 3, and 5 . Withanolides $\mathbf{1 - 5}$ elevated HSP32 levels in a concentrationdependent manner.

In this report, the heat shock effect and oxidative stress effect were abrogated following administration of $\mathrm{N}$-acetylcysteine to the cells. This stress response effect was observed only with compounds 2, 3, and 5. It is likely that the epoxide at C5-C6 in compound $\mathbf{5}$ may lead to free radical or reactive-oxygen species formation, which could explain an oxidative stress on the cells. Additionally the double bond at C5-C6 (compounds
2 and 3) may also convey some of the biologic activity seen with these molecules, as compounds 1 and $\mathbf{4}$ lack either an epoxy group or a double bond at C5-C6 and do not exhibit this stress response following treatment. Further studies, however, are warranted to validate this observation and more completely evaluate the mechanism of antiproliferative action of these withanolides.

\section{EXPERIMENTAL SECTION}

General Experimental Procedures. Optical rotations were measured with a Rudolph RS Autopol IV automatic polarimeter. IR data were obtained with a Thermo Nicolet Avatar 360 FT-IR spectrometer. NMR spectra were recorded with a Bruker AV-400 or AV-500 instrument with a cryoprobe for ${ }^{1} \mathrm{H}, \mathrm{APT}, \mathrm{COSY} / \mathrm{DQF}$ COSY, HSQC, HMBC, and NOESY/ROESY. Chemical shift values are given in $\delta(\mathrm{ppm})$ using the peak signals of the solvent $\mathrm{CDCl}_{3}\left(\delta_{\mathrm{H}}\right.$ 7.26 and $\left.\delta_{\mathrm{C}} 77.23\right)$ as references, and coupling constants are reported in Hz. ESIMS data were measured with an Agilent 1200 Series LCMS/MS ion trap 6300 mass spectrometer. HRESIMS data were collected with a LCT Premier time-of-flight mass spectrometer (Waters Corp., Milford, MA, USA). Column chromatography was performed on silica gel (particle size 12-25 $\mu \mathrm{m}$ ) (Sorbent Technologies, Atlanta, GA, USA), MCI CHP20P (particle size 75$150 \mu \mathrm{m}$ ) (Sigma-Aldrich, St. Louis, MO, USA), Sephadex LH-20 (GE Healthcare, Piscataway, NJ, USA), or $\mathrm{C}_{18}$ reversed-phase silica gel (particle size 40-65 $\mu \mathrm{m}$ ) (Sigma-Aldrich). Normal-phase silica gel G TLC plates (w/UV 254) and reversed-phase $C_{18}$ TLC plates (w/UV 254) (Sorbent Technologies) were used for fraction and compound detection. The spots were visualized using UV light at $254 \mathrm{~nm}$ and spraying with $10 \% \mathrm{EtOH}-$ sulfuric acid reagent. Semipreparative HPLC was performed on an Agilent 1200 unit equipped with a DAD detector, utilizing a Lichrospher RP-18 column $(250 \times 10 \mathrm{~mm}, 5 \mu \mathrm{m})$.

Plant Material. The fresh aerial parts of $D$. wrightii were collected in July 2010 from the Quivira National Wildlife Refuge (latitude: $38.10165^{\circ}$; longitude: $98.45496^{\circ}$ ), Stafford County, Kansas, and authenticated by Dr. Kelly Kindscher of the Kansas Biological Survey, University of Kansas, Lawrence, Kansas, United States. A voucher specimen, 4091, was deposited in the R.L. McGregor Herbarium of the University of Kansas.

Extraction and Isolation. The collected biomass was air-dried, ground to a coarse powder $(2.1 \mathrm{~kg})$, and extracted three times with $\mathrm{CH}_{2} \mathrm{Cl}_{2}-\mathrm{MeOH}(50: 50,6.0 \mathrm{~L})$ at room temperature. After removing the solvents under vacuum, the extract $(220 \mathrm{~g})$ was suspended in 400 $\mathrm{mL}$ of $\mathrm{H}_{2} \mathrm{O}$, followed by successive partitions with $n$-hexane, ethyl acetate, and $n$-butanol $(3 \times 500 \mathrm{~mL})$. The resulting $n$-BuOH fraction $(52 \mathrm{~g})$ collected was applied to a MCI CHP2OP column $(2.0 \mathrm{~kg})$ and eluted subsequently with mixtures of $\mathrm{H}_{2} \mathrm{O}-\mathrm{MeOH}$ (100:0, 80:20, $60: 40,40: 60,85: 15,0: 100)$, in order of increasing concentrations of $\mathrm{MeOH}$. The $85 \% \mathrm{MeOH}$ fraction $(12.0 \mathrm{~g})$ was subjected to silica gel $\mathrm{CC}$, eluted with $\mathrm{CH}_{2} \mathrm{Cl}_{2}-\mathrm{CH}_{3} \mathrm{COCH}_{3}$ with increasing amounts of acetone, to afford compounds withametelin $\mathrm{L}(2)$ (340 mg),

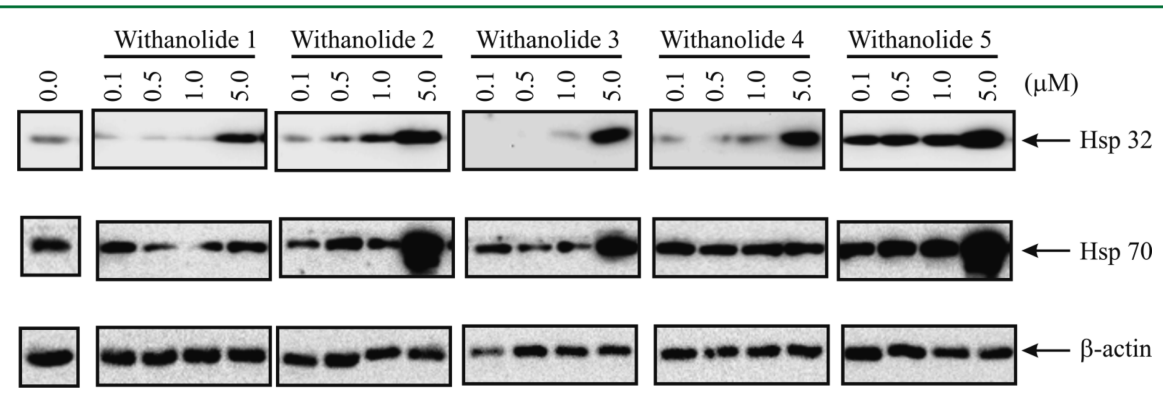

Figure 2. Western blot analysis of glioblastoma cell line U251 following treatment with withanolides 1-5. Total levels of HSP32 and HSP70, biomarkers of cellular stress and withanolide activity, were screened at $0,0.1,0.5,1$, and $5 \mu \mathrm{M}$ concentrations of each compound for $24 \mathrm{~h}$. HSP70 was markedly upregulated at $5 \mu \mathrm{M}$ with withanolides 2, 3, and 5, while HSP32 levels were elevated in a concentration-dependent manner with all compounds 1-5 tested. The $\beta$-actin protein was used as a loading control marker. 
withametelin, also known as daturilin (3) $(150 \mathrm{mg})$, withametelin $\mathrm{O}$ (4) $(12 \mathrm{mg})$, and withametelin F (5) (7 mg). The fractions eluted by $\mathrm{CH}_{2} \mathrm{Cl}_{2}-\mathrm{CH}_{3} \mathrm{COCH}_{3}$ (6:1) were subjected to semipreparative HPLC, with the mobile phase $\mathrm{CH}_{3} \mathrm{CN}-\mathrm{H}_{2} \mathrm{O}$ (44:56), to afford $1(8 \mathrm{mg})$.

Withawrightolide (1): amorphous powder; $[\alpha]^{25}+19.2(c 0.18$, $\mathrm{CHCl}_{3}$ ); UV $(\mathrm{MeOH}) \lambda_{\max }(\log \varepsilon) 226(3.05) \mathrm{nm}$; IR (neat) $\nu_{\max }$ 3435 (br), 2922, 1740, $1705 \mathrm{~cm}^{-1}$; ${ }^{1} \mathrm{H}$ NMR and ${ }^{13} \mathrm{C}$ NMR, see Table 1; ESIMS (positive-ion mode) $\mathrm{m} / z 455[\mathrm{M}+\mathrm{H}]^{+}$; HRESIMS $\mathrm{m} / z$ $477.2610[\mathrm{M}+\mathrm{Na}]^{+}$(calcd for $\left.\mathrm{C}_{28} \mathrm{H}_{38} \mathrm{O}_{5} \mathrm{Na}, 477.2617\right)$.

Single-Crystal X-ray Structure Determination of Withametelin L (2). Crystal analysis was performed with a colorless cubic crystal (dimensions $0.48 \times 0.12 \times 0.05 \mathrm{~mm}^{3}$ ) obtained from $\mathrm{CH}_{2} \mathrm{Cl}_{2}-\mathrm{CH}_{3} \mathrm{CN}(1: 1)$ using $\mathrm{Cu} \mathrm{K} \alpha$ radiation $(\lambda=1.54178 \AA)$ on a Bruker APEX2 diffractometer equipped with a Bruker MicroStar microfocus rotating anode $\mathrm{X}$-ray source and Helios multilayer optics. Crystal data for 2: $\mathrm{C}_{28} \mathrm{H}_{36} \mathrm{O}_{5}$ (formula weight 452.57), monoclinic, space group $P 2_{1}, T=100(2) \mathrm{K}$, crystal cell parameters $a=11.7590$ (3) $\AA, b=6.5766(2) \AA, c=15.0921(4) \AA, \beta=96.0790(10)^{\circ}, V=$ $1160.57(10) \AA^{3}, D_{c}=1.295 \mathrm{Mg} / \mathrm{m}^{3}, Z=2, F(000)=488$, absorption coefficient $\mu=0.700 \mathrm{~mm}^{-1}$. A total of 10166 reflections were collected in the range $2.94^{\circ}<\theta<69.26^{\circ}$, with 2971 independent reflections $\left[R_{(\mathrm{int})}=0.0155\right]$; completeness to $\theta=66^{\circ}$ was $96.5 \%$. Multiscan absorption correction applied; full-matrix least-squares refinement on $F^{2}$; the number of data/restraints/parameters were 2971/1/443; goodness-of-fit on $F^{2}=1.060$; final $R$ indices $[I>2 \sigma(I)]$, $R_{1}=0.0249, w R_{2}=0.0646 ; R$ indices (all data), $R_{1}=0.0249, w R_{2}=$ 0.0646 ; largest difference peak and hole, 0.169 and $-0.126 \mathrm{e} / \AA^{-3}$.

Cell Culture and Cell Proliferation and Viability Assay. Two human glioblastoma cell lines, U251 and U87, were generously provided by Dr. Jann Sarkaria (Mayo Clinic, Rochester, MN, USA). The head and neck squamous cell carcinoma (HNSCC) cell line MDA-1986 was a gift from Dr. Jeffrey Myers (University of Texas, M.D. Anderson Cancer Center, Houston, TX, USA). The fetal lung fibroblast cell line MRC-5 was obtained from ATCC. Cell maintenance, experimental procedures, and data presentation were similar to those previously described. ${ }^{4,14}$ The U87 and U251 cell lines were grown in DMEM (\#6429; Sigma-Aldrich) supplemented with $10 \%$ fetal bovine serum (Sigma-Aldrich) and $1 \%$ penicillin/ streptomycin $(100 \mathrm{IU} / \mathrm{mL} / 100 \mu \mathrm{g} / \mathrm{mL}$; Sigma-Aldrich). The MDA1986 and MRC-5 cell lines were grown in similar media but also supplemented with $1 \%$ L-glutamine (200 mM; Sigma-Aldrich), 1\% MEM-vitamin (100×; Hyclone, Logan, UT, USA), and 1\% MEMnonessential amino acids (Sigma Aldrich). The cells were grown in a monolayer and were incubated at $37{ }^{\circ} \mathrm{C}$ in a humidified atmosphere containing $5 \% \mathrm{CO}_{2}$ until they reached $75-90 \%$ confluence. The viability of cells after treatment with withanolides (1-5) was determined using an MTS assay. Cells were seeded in 96-well plates at 2500 cells/well in $90 \mu \mathrm{L}$ of media. Following an approximate $6 \mathrm{~h}$ incubation period, $10 \mu \mathrm{L}$ of drug-containing media in various concentrations was added to each well, and the cells were incubated for an additional $72 \mathrm{~h}$. The number of viable cells was quantified by the colorometric CellTiter96 Aqueous MTS assay (Promega, Fitchburg, WI, USA) at $490 \mathrm{~nm}$ on a BioTek Synergy 2 plate reader (BioTek, Winooski, VT, USA) as per the manufacturer's instructions. All experiments were carried out in triplicate on two separate occasions, and GraphPad (GraphPad Inc., San Diego, CA, USA) was used to generate best-fit sigmoidal dose-response curves for $\mathrm{IC}_{50}$ determination.

Western Blotting Analysis. Cells were plated at an amount previously determined, based on the growth characteristics of the cells, to have a high enough yield without achieving complete confluency upon harvest and were allowed to grow overnight. Cells were treated with appropriate concentrations of the withanolides. Upon completion of treatment, proteins were collected, quantified, separated by sodium dodecyl sulfate-polyacrylamide gel electrophoresis (SDS-PAGE), and electrotransfered onto a Hybond nitrocellulose membrane as previously described. ${ }^{4}$ Actin levels were assessed to ensure equal loading and transfer of proteins. Western analysis was completed in the human U251 cell line. Primary antibodies were utilized against HSP70 (Enzo Life Sciences, Farmingdale, NY, USA; ADI-SPA-810;
1:1000), HSP32/heme oxygenase 1 (Enzo Life Sciences; SPA-894; 1:1000), and total actin (EMD Millipore, Billerica, MA, USA; MAB1501; 1:50 000). Donkey anti-rabbit IgG HRP (sc-2313; 1:5000) and goat anti-mouse IgG HRP (sc-2005; 1:5000) secondary antibodies were acquired from Santa Cruz Biotechnology (Santa Cruz, CA, USA).

\section{ASSOCIATED CONTENT}

\section{S Supporting Information}

${ }^{1} \mathrm{H}$ and ${ }^{13} \mathrm{C}$ NMR spectra of withanolide $\mathbf{1}$ are available free of charge via the Internet at http://pubs.acs.org. Crystallographic data for the structure of $\mathbf{2}$ as reported in this paper were deposited with the Cambridge Crystallographic Data Centre, under reference number CCDC 907707. Copies of the data can be obtained, free of charge, on application to the Director, CCDC, 12 Union Road, Cambridge CB2 1EZ, UK (fax: +44(0)1223-336033 or e-mail: deposit@ccdc.cam.ac.uk).

\section{AUTHOR INFORMATION}

\section{Corresponding Author}

*Tel: +01-785-864-4844. Fax: +01-785-864-5326. E-mail: btimmer@ku.edu.

\section{Notes}

The authors declare no competing financial interest.

\section{ACKNOWLEDGMENTS}

This study was supported, in part, by grant IND 0061464 (awarded to B.N.T. and K.K.) from the Kansas Bioscience Authority (KBA) and Center for Heartland Plant Innovations (HPI). The authors also acknowledge partial financial assistance from grant NFP0066367 from the Institute for Advancing Medical Innovation (IAMI) (awarded to M.S.C. and to B.N.T.). Partial support of the in vitro experiments was provided by the University of Kansas Center for Cancer Experimental Therapeutics NIH-COBRE P20 RR015563 (PI: B.N.T., project award PI: M.S.C.). The authors are grateful to NSF-MRI grant CHE-0923449, which was used to purchase a Bruker APEX2 X-ray diffractometer and the software. The authors thank Q. Long, H. Loring, G. Beverlin, and M. Ferreira for assistance in plant collection and identification and $\mathrm{R}$. Gollapudi for initial extraction and partition of biomass.

\section{DEDICATION}

Dedicated to Dr. Lester A. Mitscher, of the University of Kansas, for his pioneering work on the discovery of bioactive natural products and their derivatives.

\section{REFERENCES}

(1) Chen, L. X.; Hao, H.; Qiu, F. Nat. Prod. Rep. 2011, 28, 705-740.

(2) Misico, R. I.; Nicotra, V. E.; Oberti, J. C.; Barboza, G.; Gil, R. R.; Burton, G. Prog. Chem. Org. Nat. Prod. 2011, 94, 127-229.

(3) Zhang, H.; Samadi, A. K.; Cohen, M. S.; Timmermann, B. N. Pure Appl. Chem. 2012, 84, 1353-1367.

(4) Samadi, A. K.; Tong, X. Q.; Mukerji, R.; Zhang, H. P.; Timmermann, B. N.; Cohen, M. S. J. Nat. Prod. 2010, 73, 1476-1481.

(5) Tong, X.; Zhang, H.; Timmermann, B. N. Phytochemistry Lett. 2011, 4, 411-414.

(6) Zhang, H.; Samadi, A. K.; Gallagher, R. J.; Araya, J. J.; Tong, X.; Day, V. W.; Cohen, M. S.; Kindscher, K.; Gollapudi, R; Timmermann, B. N. J. Nat. Prod. 2011, 74, 2532-2544.

(7) Zhang, H.; Motiwala, H.; Samadi, A.; Day, V.; Aubé, J.; Cohen, M.; Kindscher, K.; Gollapudi, R.; Timmermann, B. Chem. Pharm. Bull. 2012, 60, 1234-1239.

(8) Pan, Y.; Wang, X.; Hu, X. J. Nat. Prod. 2007, 70, 1127-1132. 
(9) Makino, B.; Kawai, M.; Kito, K.; Yamamura, H.; Butsugan, Y. Tetrahedron 1995, 51, 12529-12538.

(10) Zhu, X. H.; Ando, J.; Takagi, M.; Ikeda, T.; Yoshimitsu, A.; Nohara, T. Chem. Pharm. Bull. 2001, 49, 1440-1443.

(11) Oshima, Y.; Bagchi, A.; Hikino, H.; Sinha, S. C.; Sahai, M.; Ray, A. B. Tetrahedron Lett. 1987, 28, 2025-2028.

(12) Siddoqio., S.; Sultana, N.; Ahmad, S. S.; Haider, S. I. Phytochemistry 1987, 26, 2641-2643.

(13) Jahromi, M. A. F.; Manickam, M.; Gupta, M.; Oshima, Y.; Hatakeyama, S.; Ray, A. B. J. Chem. Res. (S) 1993, 234-235.

(14) Grogan, P. T.; Sleder, K. D.; Samadi, A. K.; Zhang, H.; Timmermann, B. N.; Cohen, M. S. Invest. New Drugs 2012, 10.1007/s 10637-012-9888-5. 